\title{
The Impacts of Climatic and Non-climatic Factors on Household Food Security: A Study on the Poor Living in the Malaysian East Coast Economic Region
}

\author{
Md. Mahmudul Alam* \\ Senior Lecturer \\ School of Economics, Finance \& Banking (SEFB) \\ College of Business (COB) \\ Universiti Utara Malaysia (UUM) \\ Sintok, Kedah, Malaysia \\ Email: rony000@gmail.com \\ Mobile: +60182467050 \\ Chamhuri Siwar \\ Emeritus Professor \\ Institute for Environment and Development (LESTARI) \\ National University of Malaysia (UKM) \\ 43600 UKM Bangi, Selangor Darul Ehsan, Malaysia \\ E-mail: csiwar@ukm.my
}

\begin{abstract}
Abu N.M. Wahid
Managing Editor, the Journal of Developing Areas

Professor, Department of Economics and Finance

Tennessee State University

Nashville, Tennessee, USA

E-mail: awahid@tnstate.edu

Tel: +615-963-7149
\end{abstract}

*corresponding author

\section{Citation Reference:}

Alam, M.M., Siwar, C., and Wahid, A.N.M. 2016. The Impacts of Climatic and Nonclimatic Factors on Household Food Security in Malaysia: A Study on the Poor Living in the Malaysian East Coast Economic Region. Asia-Pacific Development Journal. Vol. 23(1), 79-104. (online) http://www.unescap.org/sites/default/files/chapter 4.pdf

This is a pre-publication copy.

The published article is copyrighted by the publisher of the journal. 


\title{
The Impacts of Climatic and Non-climatic Factors on Household Food Security: A Study on the Poor Living in the Malaysian East Coast Economic Region
}

\begin{abstract}
Sustainable food security at household level is a national concern in many countries. The reasons for household food insecurity include social, economic, political, and personal factors as well as climatic changes and its outcomes. This research aims at finding out the linkage of the factors of climatic changes, non-climatic factors and household resiliencies with the level of household food security among the poor and low income households in Malaysia. This study is based on primary data that were collected in Jul-Oct 2012 through a questionnaire survey on 460 poor and low income households from the Pahang, Kelantan, and Terengganu States of Malaysia. The sample was selected from E-Kasih poor household database based on cluster random sampling technique. Initially the study measures household food security according to the USAID-HFIA model, and ran ordinal regressions under the logit and probit models. This study finds that household food insecurity is not only linked with social and economic factors, but also significantly linked with the climatic factors. Therefore, the food security programs need to be integrated with the adaption programs for climatic change.
\end{abstract}

Key words: Climatic Changes, Household Food Security, Poverty, Ordinal Regression, Resilience, East Coast Economic Region, Malaysia

JEL Code: I32, Q54, P48

\section{Introduction}

The 2008 global food crisis serves as a prelude to a more acute food crisis in the future. As a result, food security is now a national issue for many countries. The major food security concern is about making agricultural production sufficient for domestic consumption and capability for making food available and accessible from international markets.

Sustainable food security at the household level is also equally important because national food security is not enough to ensure sustainable food security at the household level. The drivers of household food security are in fact more crucial than national level because while food security is defined in its most basic form as access by all people at all times to foods needed for a healthy life (FAO 2003:28). As such, the focus of food security should be on the household as the basic unit in the society. This distinction is important because activities directed towards improving household food security may be quite different from those aimed at improving food security in general.

There are many factors that drive household food insecurity. According to Lovendal and Knowles (2006), these factors include political, economic, environment, natural, social, infrastructural, and health issues. Frankenberge (1992) puts forward that assets, community inequalities, risk-minimizing strategies, and coping strategy are also important drivers. Nyariki and Wiggins (1997) gives utilization of physical, natural, and human resources, availability of technology, and off-farm jobs as factors that drives household to food insecurity. Workneh (2006) mentions that the major drivers are capability to produce own food, growth of purchasing power. Iram and Butt (2004), ECA (2004), Cristofar and Basiotis 
(1992), and Olson et al. (1997) and Rose et al. (1995) adds household's demography, access to land, land tenure system, ability to utilize the land productively, and savings to the list of factors. Other researchers, such as Fartahun et al. (2007), Hindin (2006), Myntti (1993), Pfeiffer et al. (2001) Piaseu (2006) and Workneh (2006), widens the list to include women with income-earning capability, women education, sufficient income, number of children, social support, accessibility to productive resources, educational level, land holdings, accessibility to transport, livestock productivity, awareness of suitable interventions, storage technology, and unemployment level.

Changes in the climatic factors and its outcomes would also affect household food security. According to IPCC (Intergovernmental Panel on Climate Change) and Fourth Assessment Report, food security and malnutrition will be severely affected by climate change and variability (IPCC 2007a). FAO (2008 and 2007) has also stressed that climate change affects the availability of food, food supply stability, accessibility to food and utilization of food. This in turn results in negative impacts on nutrition and food security. Water scarcity and droughts reduce the nutritional diversity and decrease the general food consumption, which would cause malnutrition such as micronutrient deficiencies, proteinenergy malnutrition, and under nutrition (IPCC 2007). The increase in rainfall, temperature, sea levels, salinity give rise to flooding in human settlement areas. (Cruz et al. 2007Mimura et al. 2007). It may also causescarcity of freshwater (Kundzewicz et al. 2007), increase diarrhea and other contagious diseases (Checkley et al. 2000; Kovats et al. 2004; Zimmerman et al. 2007). Climatic changes also have impacts on food distribution, influencing people's access to markets to sell or purchase food (Abdulai and CroleRees 2001), increase food prices (Cline 2007; von Braun 2007), and reduce real income (Thomsen \& Metz 1998).

Malaysia is a fast developing country with a fairly diversified economy. According to EIA (2005), carbon dioxide $\left(\mathrm{CO}_{2}\right)$ emissions in Malaysia have increased by $221 \%$ during the period from 1990 to 2004 and is included in the list of 30 biggest greenhouse gas emitters. Global warming is expected to elevated temperature by $0.3-4.5^{\circ} \mathrm{C}$. Warmer temperature will cause sea level rise by about $95 \mathrm{~cm}$ over a hundred-year period and changes in rainfall between $-30 \%$ to $+30 \%$. It reduces crop yield and cause drought in many areas so that cultivation of some crops will not be possible (MOSTE 2001). Moreover, projections on maximum monthly precipitation to increase by $51 \%$ over Pahang, Kelantan and Terengganu, while minimum precipitation decreases between $32 \%$ and $61 \%$ for the whole of Peninsular Malaysia. Consequently, annual rainfall may increase up to $10 \%$ in Kelantan, Terengganu, Pahang and North West Coast, and decrease up to 5\% in Selangor and Johor (NAHRIM 2006). Tisdell finds that rainfall variability increases the level of environmental stress that affects the capability of the system to maintain productivity (Tisdell 1996).

Under the current climate change scenario, temperatures above $25^{\circ} \mathrm{C}$ may reduce grain mass at $4.4 \%$ per $1^{\circ} \mathrm{C}$ rise (Tashiro 1989), and grain yield may decline as much as $9.6 \%-10.0 \%$ per $1^{\circ} \mathrm{C}$ rise (Baker 1993). Singh et al. (1996) reveals that the actual farm yields of rice in Malaysia vary from 3-5 tons per hectare, where potential yield is 7.2 tons. The study also unfolds that there is a decline in rice yield between $4.6 \%-6.1 \%$ per $1{ }^{\circ} \mathrm{C}$ temperature increase and that doubling of $\mathrm{CO}_{2}$ concentration (from present level of $340 \mathrm{ppm}$ to $680 \mathrm{ppm}$ ) which may offset the detrimental effect of $4^{\circ} \mathrm{C}$ temperature increase on rice production in Malaysia. Overall, based on the analysis of minimum and maximum yield of the last 28 years, the macro cases of the national data from 1980 to 2008 of Malaysia show that the yield of paddy would decrease between $43 \%$ and $61 \%$ if there is a $1{ }^{\circ} \mathrm{C}$ temperature and 1 millimeter (mm) rainfall increase (Ali and Ali 2009). In a recent study, based on the 
micro data on paddy field of Integrated Agricultural Development Area (IADA), it was found that in North-West Selangor, temperature increased by $1 \%$ which might lead to $3.44 \%$ decrease in current paddy yield and $0.03 \%$ decrease in paddy yield in the following season; and rainfall increased by $1 \%$ which might lead to $0.12 \%$ decrease in current paddy yield and $0.12 \%$ decrease in paddy yield in the following season (Alam et al. 2014).

Malaysia joined 185 other nations in signing the Declaration of Rome at the 1996 International Food Summit, pledging to reduce the prevalence of hunger by at least $50 \%$, within its own jurisdiction, by a target date some time in the early $21^{\text {st }}$ century. However, in Malaysia, the food security has been embedded into the theme of self-sufficiency level that referred to paddy or rice sector only (Arshad et al. 1999; Alam et al. 2011; 2012a), instead of having a specific or special policy on overall food security. To ensure food security in Malaysia, the government adopts two strategies, such as establishing self-sufficiency level and building rice stocks both domestically and internationally. However, Malaysia has never met the food self-sufficiency level. About $10 \%$ to $35 \%$ of total required rice is imported from neighboring countries, such as Thailand, Vietnam, Myanmar, India, and Pakistan. The highest food self-sufficiency level for the country was $95 \%$ and the lowest was $65 \%$, which were recorded in 1975 and 1990 respectively.

As climate change is one of the major potential threats to national food security in Malaysia, there is a strong possibility that climatic change is linked with household food security of the country. To ensure food security and proper policy options in Malaysia, it is very important to study the current situation of household food security and the linkage between the changes in climatic factors and sustainable food security at household level. Very few works have been conducted on the impacts of changes in climatic factors and its' outcomes on household food security in Malaysia (Alam et al., 2016a; 2016b). Hence, this paper is an attempt to conduct an in depth study on this issue. The findings of this study will be helpful for the policy makers to achieve the Vision 2020 - to become a fully developed nation by the year of 2020 - and setting targets in national development plans on food security, socioeconomic betterment, and poverty alleviation.

\section{Data, Model and Methodology}

\subsection{Data Collection}

For the empirical assessment, this study mostly relies on primary data that are collected through an extensive questionnaire survey at household level in East Coast Economic Region (ECER) in Malaysia. This study has selected ECER as the study area because ECER is more than half of the Peninsular Malaysia with the area of about 66,000 sq kilometer that covers the states Kelantan, Terengganu, Pahang, and the district of Mersing in Johor (Figure 1). ECER is very crucial for two major reasons; (a) ECER is the most vulnerable area in Malaysia due to climatic changes and (b) the income level of this region is low and poverty rate is high that is a hindrance to achieve vision 2020 (Alam et al., 2012b; ECER Master Plan. 2007, 2008). The population of ECER was about 3.95 million, which represents $14.8 \%$ of the total population of Malaysia in 2005. In 2004 the incidences of poverty were $10.6 \%, 4 \%$, and $15.4 \%$ in Kelantan, Pahang, and Terengganu respectively, whereas for overall Malaysia it was $5.7 \%$, and the incidences of hardcore poverty were $1.3 \%$, $1.0 \%$, and $4.4 \%$ in Kelantan, Pahang, and Terengganu respectively, whereas for overall Malaysia it was $1.2 \%$. At that time, there were about 45,000 paddy farmers in the ECER, and 
the average productivity per worker was RM 11,915 whereas the national agriculture productivity per worker was RM 15,355.

ECER is mainly an agricultural region. In 2004, all crops production covered a total area of 2.22 million ha in the ECER (34.8\% of Peninsular Malaysia). However, in 2008 government officially launched a very large development project to develop five key areas manufacturing, oil, gas \& petrochemicals, tourism, agriculture and human capital development. With the objective of fast-forwarding the inflow of FDI and industrialization in the region, ECER Special Economic Zone (ECER SEZ) and Malaysia-China Kuantan Industrial Park were initiated in this area. Therefore, ECER is expected to implement projects worth an estimated RM 112 billion in value by year 2020. The ECER Special Economic Zone (SEZ) is expected to generate up to RM 90 billion in investments and contribute RM 23 billion to the national GDP, as well as create 220,000 new jobs out of the 560,000 jobs identified.

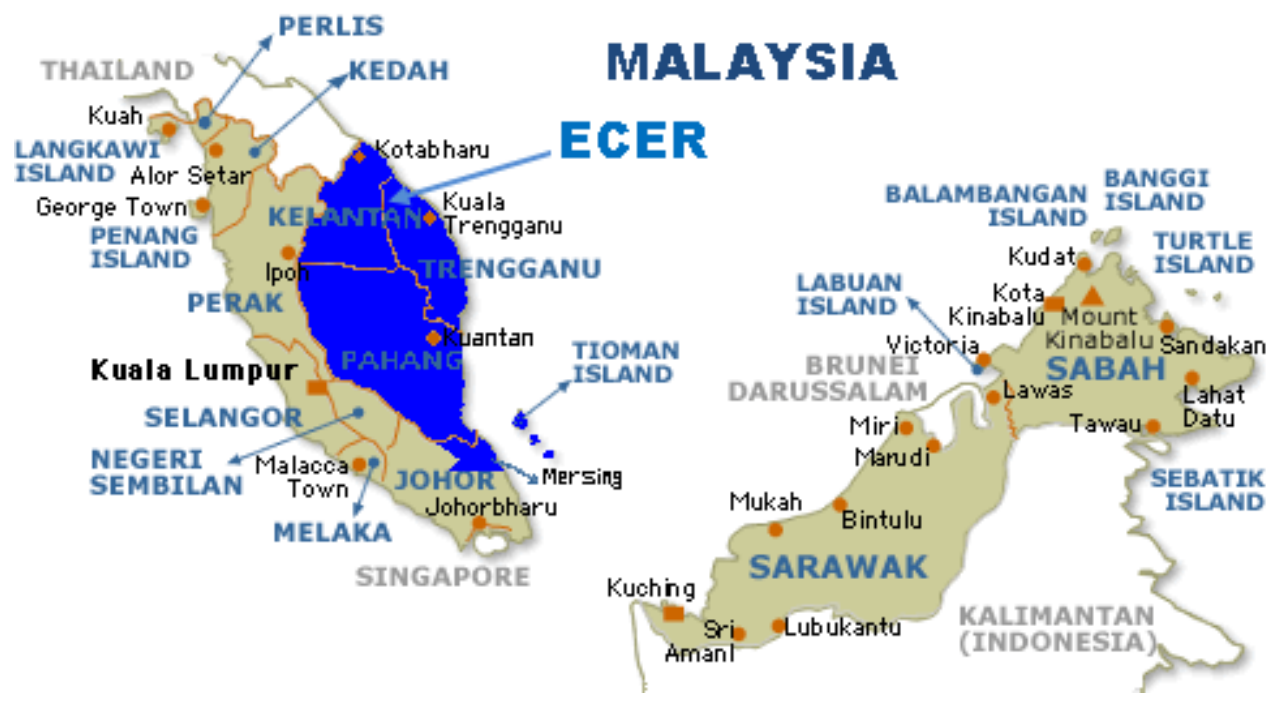

Figure 1: Location of the Study Area (ECER-Malaysia)

Source: Alam et al., 2012b

The study follows two-stage cluster random sampling technique. Initially the samples are clustered by location and then by poverty category. Finally, from each category, samples are picked randomly from the E-Kasih database - which is an integrated database system that enlisted poor households at the national level to plan, implement and monitor poverty programs. The urban area of Kuantan and rural area of Pekan is selected from Pahang state. The urban area of Kota Bharu and rural area of Tumpat is selected from Kelantan state. The urban area of Kuala Terengganu and rural area of Marang is selected from Terengganu state.

Based on the formula of required size of samples (Yamane, 1967: 886), first, 400 households were selected according to the proportion of population distribution. However, to ensure a good number of observations for each group, which was needed for sound statistical analysis for any particular group, another 100 households were added to the sample. However, while targeting the sample size to be 500, after collecting and validating the data, finally, 460 households remained in the sample. The final distribution of the collected sample is given in the Table 1 . 
Table 1: Distribution of the Sample of the Study

\begin{tabular}{rrrrrrrrrr}
\hline & \multicolumn{1}{c}{ Pahang } & \multicolumn{2}{c}{ Kelantan } & \multicolumn{2}{c}{ Terengganu } & \multicolumn{2}{c}{ Total } & \multicolumn{2}{c}{ All } \\
& Urban & Rural & Urban & Rural & Urban & Rural & Urban & Rural & Total \\
\hline \hline Hard core Poor & 2 & 15 & 33 & 22 & 6 & 32 & 41 & 69 & 110 \\
Poor & 12 & 14 & 21 & 34 & 27 & 46 & 60 & 94 & 154 \\
$\begin{array}{r}\text { Recently Marginally } \\
\text { Non-poor }\end{array}$ & 11 & 9 & 15 & 16 & 4 & 16 & 30 & 41 & 71 \\
$\begin{array}{r}\text { Marginally Non- } \\
\text { poor }\end{array}$ & 18 & 30 & 32 & 25 & 4 & 16 & 54 & 71 & 125 \\
\hline Total Target Group & 43 & 68 & 101 & 97 & 41 & 110 & 185 & 275 & 460 \\
\hline State Total & & 111 & & 198 & & 151 & & 460 & \\
\hline
\end{tabular}

* In the E-Kasih system, the rural poverty data were categorized as monthly income per person up to RM110 is hard-core poor, up to RM185 is poor, and up to RM227 is marginally non-poor, and for urban area up to RM120 is hard-core poor, up to RM200 is poor, and up to RM340 is marginally nonpoor.

A face-to-face interview based on structured questionnaire is used to collect data, where the respondents provide the answers and the enumerators filled-up the questionnaire. The survey is conducted by the regular enumerators of the Implementation Coordination Unit (ICU) agency from Pahang, Kelantan, and Terengganu in Jul-Oct 2012.

\subsection{Model Specification}

To measure the relationship between household status of food security and the climatic and general factors affecting on food security, the following ordered dependent regression or ordinal regression is conducted based on logit and probit models:

$$
\begin{aligned}
& \mathrm{Z}_{\mathrm{i}}=(\mathrm{Y} 1, \mathrm{Y} 2) \\
& \mathrm{X}_{\mathrm{i}}=(\mathrm{X} 1, \ldots, \mathrm{X} 63) \\
& \mathrm{Z}_{\mathrm{i}}=f\left(\mathrm{X}_{\mathrm{i}}\right)
\end{aligned}
$$

In this study, the two dependent variables, the household status of food accessibility and household food availability, are considered as the measurements of household food security. Household food availability is based on measurement on the direct perception of the household, where household status of food accessibility measurement was based on the frequency of calculation. To measure the status of household food availability, households have been asked about their food status in last one month (see Table 2), and to measure the status of household food accessibility, this study follows direct measuring questionnairebased techniques developed by Coates et al. (2007) for USAID which is known as Household Food Insecurity Access (HFIA) (Table 3).

The list of the independent variables of the study consists of different resilience factors of household (X1-X18), non-climatic factors (X18-X44), and climatic factors (X45$\mathrm{X63)}$. These variables are considered from all of the four dimensions of food security availability of food, stability of supply, accessibility to food, and utilization of food (FAO, 2005,2008 ). The availability of food means sufficient quantities of quality food available at household level. The accessibility of food means household's access to sufficient resources, including a set of all commodity bundles that an individual can gain access based on the legal, economic, political, and social arrangement of a community in which they live, for getting quality foods for a nutritious meal. Food utilization shows the significance of nonfood inputs in food security such as proper diet, clean water, healthcare, and sanitation to gain 
nutritional well-being where all physiological requirements are met. Food system stability refers to a households having access to sufficient food at all times so that they should not risk losing access to food as a result of sudden crisis such as an economic or climatic crisis or cyclical occurrence such as seasonal food insecurities. Here, the resilience refers to the households' capacity or strength to cope with stress and hardship in case of actual or expected food insecurity which are categorized as socioeconomic, physical assets, and livelihood strategy and behavior. The measurements of all of the variables are given in the appendix.

To check the best fit model and robustness, this study reports both the probit and logit model, but for analysis it mostly focuses on the logit model. Logit and probit model looks like a sigmoid function with a domain between 0 and 1 , which makes them both quantile functions based on the assumption that logit model that follows logistic distribution and probit model follows normal distribution. Normally, pogit model is used when every observation has equal probability. Furthermore, a correlation analysis is undertaken in order to find out the relationship among the relevant variables and to check the multicollinearity problem. Finally, this study also justifies how the endogeneity and causality problems are considered under the study.

\section{Results and Discussion}

\subsection{Measurement of Household Food Security}

In terms of household food availability, $14.8 \%$ say they have enough food what they like, but majority $(41.1 \%)$ of the households mention that always they don't have enough kind of food they like. $9.1 \%$ of the households mention that they frequently stay hungry (Table 2).

Table 2: Family Food Status in Last One Month

\begin{tabular}{lcc}
\hline Food Status in the Family & No of Households & \% of Total \\
\hline \hline Enough of the kinds of food you want to eat & 68 & $14.8 \%$ \\
Enough but not always the kinds of food you want & 189 & $41.1 \%$ \\
Sometimes not enough to eat & 100 & $21.7 \%$ \\
Often not enough to eat & 61 & $13.3 \%$ \\
Frequently stay hungry & 42 & $9.1 \%$ \\
\hline Total & 460 & $100 \%$ \\
\hline
\end{tabular}

Household Food Insecurity Access (HFIA) is calculated for each household by assigning a code 1-4, where 1=Food Secure Access, 2=Mildly Food Insecure Access, 3=Moderately Food Insecure Access, 4=Severely Food Insecure Access. Initially the data are coded frequency-of-occurrence as 0 for all cases where the answer to the corresponding occurrence question is "no" (i.e., if $\mathrm{Q} 1=0$ then $\mathrm{Q} 1 \mathrm{a}=0$, etc.). Then the intensities of the occurrence of nine questions are measured in three frequencies - rarely (1-2 times per month) or sometimes (3-10 times) or often (10+ times per month) - which indicate by Q1a to Q9a (Table 3). Finally, the four food accessibility categories are created sequentially, to ensure that households are classified according to their most severe response.

$$
\begin{aligned}
& \text { - Category = } 1 \text { if }[(\mathrm{Q} 1=0 \text { or } \mathrm{Q} 1=1) \text { and } \mathrm{Q} 2=0 \text { and } \mathrm{Q} 3=0 \text { and } \mathrm{Q} 4=0 \\
& \text { and } \mathrm{Q} 5=0 \text { and } \mathrm{Q} 6=0 \text { and } \mathrm{Q} 7=0 \text { and } \mathrm{Q} 8=0 \text { and } \mathrm{Q} 9=0]
\end{aligned}
$$


- Category $=2$ if $[(\mathrm{Q} 1 \mathrm{a}=2$ or $\mathrm{Q} 1 \mathrm{a}=3$ or $\mathrm{Q} 2 \mathrm{a}=1$ or $\mathrm{Q} 2 \mathrm{a}=2$ or $\mathrm{Q} 2 \mathrm{a}=3$ or

$\mathrm{Q} 3 \mathrm{a}=1$ or $\mathrm{Q} 4 \mathrm{a}=1$ ) and $\mathrm{Q} 5=0$ and $\mathrm{Q} 6=0$ and $\mathrm{Q} 7=0$ and

$\mathrm{Q} 8=0$ and $\mathrm{Q} 9=0]$

- Category $=3$ if $[(\mathrm{Q} 3 \mathrm{a}=2$ or $\mathrm{Q} 3 \mathrm{a}=3$ or $\mathrm{Q} 4 \mathrm{a}=2$ or $\mathrm{Q} 4 \mathrm{a}=3$ or $\mathrm{Q} 5 \mathrm{a}=1$ or

$\mathrm{Q} 5 \mathrm{a}=2$ or $\mathrm{Q} 6 \mathrm{a}=1$ or $\mathrm{QQ6}=2$ ) and $\mathrm{Q} 7=0$ and $\mathrm{Q} 8=0$

and $\mathrm{Q} 9=0]$

- Category $=4$ if $[\mathrm{Q} 5 \mathrm{a}=3$ or $\mathrm{Q} 6 \mathrm{a}=3$ or $\mathrm{Q} 7 \mathrm{a}=1$ or $\mathrm{Q} 7 \mathrm{a}=2$ or $\mathrm{Q} 7 \mathrm{a}=3$ or

$\mathrm{Q} 8 \mathrm{a}=1$ or $\mathrm{Q} 8 \mathrm{a}=2$ or $\mathrm{Q} 8 \mathrm{a}=3$ or $\mathrm{Q} 9 \mathrm{a}=1$ or $\mathrm{Q} 9 \mathrm{a}=2$ or

$\mathrm{Q} 9 \mathrm{a}=3]$

The following table illustrates the above four categorizations, where every household is placed in a single, unique category based on the set of the responses (Table 3).

Table 3: Measurement of Household Food Insecurity Access Scale

\begin{tabular}{|c|c|c|c|c|}
\hline & \multirow[b]{2}{*}{ HFIAS Measurement Issues } & \multicolumn{3}{|c|}{ Category of food insecurity (access) } \\
\hline & & $\begin{array}{l}\text { Rarely (1-2 times } \\
\text { per month) }\end{array}$ & $\begin{array}{l}\text { Sometimes } \\
\text { (3-10 times) }\end{array}$ & $\begin{array}{l}\text { Often }(10+\text { times } \\
\text { per month) }\end{array}$ \\
\hline Q1 & Worry about food & & & \\
\hline Q2 & Unable to eat prefer food & & & \\
\hline Q3 & Eat just a few kinds of foods & & & \\
\hline Q4 & Eat foods they really do not want eat & & & \\
\hline Q5 & Eat a smaller meal & & & \\
\hline Q6 & Eat fewer meals in a day & & & \\
\hline Q7 & No food of any kinds in the household & & & \\
\hline Q8 & Go to sleep hungry & & & \\
\hline Q9 & Go to whole day and night without eating & & & \\
\hline & 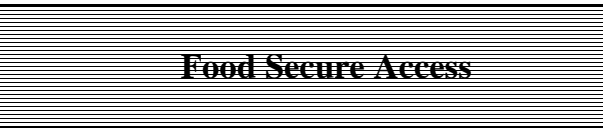 & $\begin{array}{l}\text { Mildly Food } \\
\text { Insecure }\end{array}$ & $\begin{array}{c}\text { Moderately } \\
\text { Food } \\
\text { Insecure } \\
\end{array}$ & $\begin{array}{l}\text { Sererely hod } \\
\text { Insecure }\end{array}$ \\
\hline
\end{tabular}

Source: Coates et al. 2007; Alam et al. 2016a

Based on the survey, this study finds that $52.8 \%$ of the households are under the category of "food secure access". Among the surveyed households, 23.3\% are facing mildly food insecurity (access) who are worried about not having enough food sometimes or often, and/or unable to eat preferred foods, and/or rarely eat a more monotonous diet than desired and/or also rarely eat some undesirable foods (Table 4).

Table 4: Distribution of Household Food Insecurity Access (HFIA)

\begin{tabular}{lcc}
\hline \multicolumn{1}{c}{ HFIA Category } & HFIA Prevalence & \% of HFIA Prevalence \\
\hline \hline 1= Food secure Access & 243 & $52.8 \%$ \\
2= Mildly Food Insecure Access & 107 & $23.3 \%$ \\
3= Moderately Food Insecure Access & 66 & $14.3 \%$ \\
4= Severely Food Insecure Access & 44 & $9.6 \%$ \\
\hline Total & 460 & $100.0 \%$ \\
\hline
\end{tabular}


Among the households, $14.3 \%$ are moderately food insecure. These households frequently sacrifice quality of food by eating a monotonous diet or undesirable foods sometimes or often, and/or reduce eating the quantity of food rarely or sometimes. There are $9.6 \%$ of households that are severely food insecure who has graduated to cutting back on meal size or number of meals often, and/or experiences any of the three most severe conditions - running out of food, going to bed hungry, or going a whole day and night without eating - even as infrequently as rarely or at least once in the previous month (see details in Alam et al. 2016a).

\subsection{Household Status of Food Security and Relevant Factors}

The regression models based on Equation 1 show that some of the resilience factors have statistically significant relationship with household food availability and food accessibility (Table 5). The P-values of the likelihood ratio (LR) statistics for both models are shown below 0.0000001 that suggest a very good fit of the models. The pseudo R-squares are 0.354 for food availability and 0.305 for the food accessibility models.

Results for household food availability (Y1) models indicate that the climatic impacts on kitchen environment (X58) and sanitation system (X60) are statistically significant. Among the non-climatic/general factors, competition for common resources (X31), common resources dependency for cattle or livestock feeding (X30), incidences of disease like dengue, malaria, heat stretch, cold, skin disease (X44), having knowledge about taking precaution against dengue, malaria (X17), buying bulk amount of food (X12), household poverty/economic status (X3), earning ratio (X6), and number of school going children (X2) are statistically significant.

Table 5: Relationship between Household Status of Food Security and Relevant Climatic and Non-climatic/General Factors

\begin{tabular}{|c|c|c|c|c|c|c|c|c|}
\hline \multirow[b]{3}{*}{ Variable } & \multicolumn{4}{|c|}{ Dependent variable Y1 } & \multicolumn{4}{|c|}{ Dependent variable Y2 } \\
\hline & \multicolumn{2}{|c|}{ Ordered Probit } & \multicolumn{2}{|c|}{ Ordered Logit } & \multicolumn{2}{|c|}{ Ordered Probit } & \multicolumn{2}{|c|}{ Ordered Logit } \\
\hline & Odds Ratio & Prob. & $\begin{array}{l}\text { Odds } \\
\text { Ratio }\end{array}$ & Prob. & $\begin{array}{l}\text { Odds } \\
\text { Ratio }\end{array}$ & Prob. & $\begin{array}{l}\text { Odds } \\
\text { Ratio }\end{array}$ & Prob. \\
\hline \multicolumn{9}{|c|}{ Household resilience factors: socioeconomic } \\
\hline $\mathrm{X} 1$ & 1.114 & 0.449 & 1.302 & 0.318 & 0.994 & 0.956 & 1.004 & 0.981 \\
\hline $\mathrm{X} 2$ & $0.722 *$ & 0.007 & $0.528 *$ & 0.005 & $0.652 *$ & 0.000 & $0.486 *$ & 0.000 \\
\hline $\mathrm{X} 3$ & $0.739 *$ & 0.002 & $0.590 *$ & 0.003 & $0.821 *$ & 0.004 & $0.719 *$ & 0.005 \\
\hline $\mathrm{X} 4$ & 1.264 & 0.467 & 1.822 & 0.306 & $2.315^{*}$ & 0.002 & $4.191 *$ & 0.002 \\
\hline $\mathrm{X} 5$ & 0.982 & 0.964 & 0.846 & 0.828 & 0.865 & 0.558 & 0.760 & 0.521 \\
\hline X6 & 1.181 & 0.136 & $1.412 \sim$ & 0.092 & $1.385^{*}$ & 0.001 & $1.800 *$ & 0.001 \\
\hline X7 & 1.193 & 0.542 & 1.404 & 0.521 & $1.489 \sim$ & 0.093 & 1.811 & 0.146 \\
\hline \multicolumn{9}{|c|}{ Household resilience factors: physical assets } \\
\hline $\mathrm{X} 8$ & 0.830 & 0.467 & 0.690 & 0.430 & 1.275 & 0.195 & 1.473 & 0.222 \\
\hline X9 & 1.065 & 0.825 & 1.017 & 0.974 & 1.289 & 0.210 & 1.466 & 0.278 \\
\hline $\mathrm{X} 10$ & 0.857 & 0.294 & 0.741 & 0.263 & 1.044 & 0.684 & 1.104 & 0.592 \\
\hline X11 & 1.445 & 0.176 & 1.801 & 0.232 & $1.797 *$ & 0.002 & $2.769 *$ & 0.001 \\
\hline \multicolumn{9}{|c|}{ Household resilience factors: livelihood strategy and behavior } \\
\hline $\mathrm{X} 12$ & $2.098^{*}$ & 0.006 & $4.046^{*}$ & 0.006 & 1.057 & 0.754 & 1.080 & 0.796 \\
\hline $\mathrm{X} 13$ & 1.074 & 0.623 & 1.144 & 0.631 & 1.051 & 0.634 & 1.091 & 0.624 \\
\hline $\mathrm{X} 14$ & 1.220 & 0.221 & 1.444 & 0.220 & 1.194 & 0.153 & 1.333 & 0.182 \\
\hline X15 & 0.782 & 0.269 & 0.632 & 0.274 & 1.119 & 0.456 & 1.202 & 0.478 \\
\hline X16 & 1.085 & 0.616 & 1.139 & 0.665 & 1.049 & 0.683 & 1.074 & 0.724 \\
\hline
\end{tabular}




\begin{tabular}{|c|c|c|c|c|c|c|c|c|}
\hline X17 & $1.673^{\wedge}$ & 0.039 & $2.602^{\wedge}$ & 0.035 & 1.026 & 0.851 & 1.058 & 0.809 \\
\hline \multicolumn{9}{|c|}{ Non-climatic factors } \\
\hline X18 & 0.839 & 0.318 & 0.657 & 0.182 & 1.035 & 0.775 & 1.028 & 0.892 \\
\hline X19 & 1.212 & 0.201 & 1.475 & 0.165 & 1.022 & 0.851 & 1.041 & 0.836 \\
\hline $\mathrm{X} 20$ & 1.222 & 0.228 & 1.500 & 0.194 & 0.992 & 0.944 & 0.994 & 0.977 \\
\hline $\mathrm{X} 21$ & 1.079 & 0.677 & 1.144 & 0.688 & 1.051 & 0.675 & 1.109 & 0.603 \\
\hline $\mathrm{X} 22$ & 0.828 & 0.299 & 0.676 & 0.234 & $0.791 \sim$ & 0.079 & $0.663 \sim$ & 0.073 \\
\hline $\mathrm{X} 23$ & 1.114 & 0.495 & 1.246 & 0.444 & $0.760^{\wedge}$ & 0.018 & $0.630^{\wedge}$ & 0.019 \\
\hline $\mathrm{X} 24$ & 1.087 & 0.485 & 1.169 & 0.473 & 0.947 & 0.543 & 0.936 & 0.660 \\
\hline $\mathrm{X} 25$ & 1.168 & 0.301 & 1.417 & 0.219 & 1.038 & 0.740 & 1.077 & 0.697 \\
\hline $\mathrm{X} 26$ & 0.873 & 0.290 & 0.772 & 0.268 & $0.809^{\wedge}$ & 0.022 & $0.682^{\wedge}$ & 0.016 \\
\hline $\mathrm{X} 27$ & 1.075 & 0.657 & 1.155 & 0.624 & 1.100 & 0.385 & 1.183 & 0.365 \\
\hline $\mathrm{X} 28$ & 0.933 & 0.649 & 0.876 & 0.645 & 0.945 & 0.617 & 0.913 & 0.631 \\
\hline X29 & 1.235 & 0.123 & 1.355 & 0.221 & 0.917 & 0.401 & 0.846 & 0.349 \\
\hline X30 & $1.343^{\wedge}$ & 0.041 & $1.823^{\wedge}$ & 0.025 & 0.967 & 0.751 & 0.927 & 0.674 \\
\hline X31 & $0.803 \sim$ & 0.092 & $0.662 \sim$ & 0.076 & 1.127 & 0.227 & 1.246 & 0.199 \\
\hline X32 & 1.084 & 0.526 & 1.133 & 0.600 & 1.023 & 0.830 & 1.046 & 0.807 \\
\hline X33 & 0.855 & 0.302 & 0.710 & 0.226 & 1.062 & 0.598 & 1.140 & 0.504 \\
\hline X34 & 0.820 & 0.252 & 0.693 & 0.245 & 0.840 & 0.211 & 0.763 & 0.259 \\
\hline X35 & 1.121 & 0.527 & 1.288 & 0.451 & 0.877 & 0.369 & 0.755 & 0.268 \\
\hline X36 & 0.935 & 0.680 & 0.877 & 0.661 & 0.833 & 0.130 & 0.731 & 0.127 \\
\hline X37 & 0.959 & 0.786 & 0.919 & 0.764 & 1.175 & 0.177 & 1.328 & 0.164 \\
\hline X38 & 1.148 & 0.418 & 1.200 & 0.565 & 1.180 & 0.190 & 1.319 & 0.197 \\
\hline X39 & 1.084 & 0.530 & 1.240 & 0.371 & 1.068 & 0.463 & 1.124 & 0.447 \\
\hline $\mathrm{X} 40$ & 0.803 & 0.186 & 0.661 & 0.166 & 0.909 & 0.407 & 0.872 & 0.482 \\
\hline X41 & 0.833 & 0.130 & 0.708 & 0.124 & 1.140 & 0.214 & 1.267 & 0.184 \\
\hline $\mathrm{X} 42$ & 0.983 & 0.881 & 0.960 & 0.843 & 1.131 & 0.136 & 1.253 & 0.109 \\
\hline X43 & 0.761 & 0.166 & 0.591 & 0.145 & $1.503^{*}$ & 0.001 & $2.024 *$ & 0.001 \\
\hline X44 & $1.817^{*}$ & 0.001 & $3.179 *$ & 0.001 & $0.839 \sim$ & 0.102 & $0.741 \sim$ & 0.098 \\
\hline \multicolumn{9}{|c|}{ Climatic factors } \\
\hline $\mathrm{X} 45$ & 0.866 & 0.311 & 0.797 & 0.385 & $0.844 \sim$ & 0.098 & $0.747 \sim$ & 0.094 \\
\hline $\mathrm{X} 46$ & 0.688 & 0.152 & 0.465 & 0.126 & $0.489 *$ & 0.000 & $0.303 *$ & 0.000 \\
\hline $\mathrm{X} 47$ & 0.868 & 0.338 & 0.752 & 0.297 & 0.847 & 0.137 & 0.757 & 0.142 \\
\hline $\mathrm{X} 48$ & 1.308 & 0.221 & 1.450 & 0.344 & $1.631 *$ & 0.001 & $2.269 *$ & 0.001 \\
\hline X49 & 0.981 & 0.924 & 1.104 & 0.794 & 0.806 & 0.153 & 0.695 & 0.160 \\
\hline $\mathrm{X} 50$ & 1.061 & 0.722 & 1.046 & 0.888 & 0.980 & 0.873 & 0.979 & 0.919 \\
\hline X51 & 0.946 & 0.682 & 0.899 & 0.675 & 1.059 & 0.565 & 1.129 & 0.487 \\
\hline X52 & 1.060 & 0.648 & 1.150 & 0.537 & 0.996 & 0.968 & 0.983 & 0.917 \\
\hline X53 & 1.003 & 0.983 & 1.035 & 0.888 & 1.114 & 0.303 & 1.195 & 0.313 \\
\hline X54 & 0.906 & 0.471 & 0.840 & 0.498 & 0.906 & 0.325 & 0.855 & 0.366 \\
\hline X55 & 1.212 & 0.213 & 1.483 & 0.154 & 1.061 & 0.626 & 1.109 & 0.616 \\
\hline X56 & 0.857 & 0.344 & 0.757 & 0.337 & 1.055 & 0.665 & 1.075 & 0.728 \\
\hline X57 & 0.985 & 0.926 & 0.972 & 0.921 & 0.935 & 0.591 & 0.892 & 0.595 \\
\hline $\mathrm{X} 58$ & $0.564^{*}$ & 0.002 & $0.329 *$ & 0.001 & 0.832 & 0.150 & 0.718 & 0.132 \\
\hline X59 & 1.358 & 0.100 & 1.690 & 0.114 & 1.032 & 0.823 & 1.073 & 0.770 \\
\hline X60 & $1.357^{\wedge}$ & 0.046 & $1.828^{\wedge}$ & 0.035 & 1.210 & 0.104 & $1.403 \sim$ & 0.099 \\
\hline X61 & 0.811 & 0.153 & 0.680 & 0.147 & 0.876 & 0.218 & 0.787 & 0.192 \\
\hline X62 & 0.802 & 0.152 & 0.692 & 0.192 & 0.837 & 0.104 & $0.731 \sim$ & 0.091 \\
\hline X63 & 0.889 & 0.331 & 0.801 & 0.305 & 1.113 & 0.266 & 1.189 & 0.291 \\
\hline $\begin{array}{l}\text { Pseudo R- } \\
\text { squared }\end{array}$ & \multicolumn{2}{|c|}{0.350} & \multicolumn{2}{|c|}{0.354} & \multicolumn{2}{|c|}{0.306} & \multicolumn{2}{|c|}{0.305} \\
\hline $\begin{array}{l}\text { Prob (LR } \\
\text { statistic) }\end{array}$ & \multicolumn{2}{|c|}{$<0.0000001$} & \multicolumn{2}{|c|}{$<0.0000001$} & \multicolumn{2}{|c|}{$<0.0000001$} & \multicolumn{2}{|c|}{$<0.0000001$} \\
\hline Sample Size & \multicolumn{2}{|c|}{460} & \multicolumn{2}{|c|}{460} & \multicolumn{2}{|c|}{460} & \multicolumn{2}{|c|}{460} \\
\hline
\end{tabular}

$*, \wedge, \sim$ indicates significant at 1\%,5\%,10\% significance level, respectively

In terms of odds ratios, results from the availability of food at household (Y1) logit model indicates that holding other things constant, for a unit increase in the common resources dependency for cattle or livestock feeding (X30), the odds in favor of availability 
of food at household (Y1) increases by 1.823 or about $82.3 \%$. Similarly, there is a $160.2 \%$ increase of odds of availability of food in the household (Y1) for a one-unit increase in knowledge about taking precaution against dengue, malaria (X17). The odds of household food availability (Y1) for household buying bulk amount of food (X12) is 304.6\% higher than the odds of household food availability (Y1) for household without buying bulk amount of food. For a unit increase in the earning ratio (X6), the odds in favor of availability of food at household (Y1) increases by 1.412 or about $41.2 \%$

Holding other things constant, for a unit increase in climatic issues affecting kitchen environment (X58) where the odds in favor of unavailability of food in the household (Y1) increases by (1-0.329) or about $67.1 \%$. Similarly, there is a $33.8 \%$ increase of odds of unavailability of food at household (Y1) for a one-unit increase in competition for common resources (X31). For a unit increase in poverty level or decrease of household poverty/economic status (X3), the odds in favor of unavailability of food at household (Y1) increases by (1-0.59) or about $41 \%$. Similarly, there is a $47.2 \%$ increase of odds of unavailability of food at household (Y1) for a one-unit increase in number of school going children (X2).

Results for household status of food accessibility (Y2) models show that among the climatic factors, natural disasters at local level (X45), and climatic impact on income (X46), climatic impact on household food storage system (X48), climatic impact on household sanitation system (X60), and climatic impact on increases of short term food prices (X62) are statistically significant. Among the non-climatic/general factors, prices of general food items (X22), difference between rural and city food prices (X23), low level of income (X26), incidences of mosquitoes, insects, pest (X43), incidences of disease (X44), household transportation (X11), household poverty/economic status (X3), earning ratio (X6), spouse doing job (X4), and number of school going children (X2) are statistically significant. According to the probit model, households having savings (X7) also show a statistically significant relationship with household status of food accessibility.

With reference to the food accessibility at household (Y2) logit model, the odds ratio indicate that holding other things constant, for a unit increase in climatic impact on household food storage system (X48), the odds in favor of food security at household (Y2) increases by 2.269 or about $126.9 \%$. Similarly, there is a $80 \%$ increase of odds of food accessibility at household (Y2) for a one-unit increase earning ratio (X6). The odds of household food accessibility (Y2) for household having transportation (X11) is $176.9 \%$ higher than the odds of household without having transportation. The odds of household accessibility (Y2) for spouse doing job (X4) is $319.1 \%$ higher than the odds of household without spouse doing job. The odds of household food accessibility (Y2) for household have savings (X7) is $48.9 \%$ higher than the odds of household without having savings.

For this model, the odds on climatic factors indicate that holding other things constant, for a unit increase in natural disasters at local level (X45), the odds in favor of food accessibility at household (Y2) decreases by (1-0.747) or about $25.3 \%$. Similarly, there is a $69.7 \%$ decrease of odds of food accessibility at household (Y2) for a one-unit increase in climatic impact on income (X46). For a unit increase in climatic impact on increases of short time food prices (X62), the odds in favor of food accessibility at household (Y2) decreases by (1-0.731) or about $26.9 \%$. Similarly, there is a $33.7 \%$ decrease of odds of food accessibility at household (Y2) for a one-unit increase in prices of general food items (X22). For a unit increase in difference between rural and city food prices (X23), the odds in favor of food 
accessibility at household (Y2) decreases by (1-0.63) or about 37\%. Similarly, there is a $31.8 \%$ decrease of odds of food accessibility at household (Y2) for a one-unit increase in low level of income (X26). For a unit increase in incidences of disease (X44), the odds in favor of food accessibility at household (Y2) decreases by (1-0.741) or about $25.9 \%$. Similarly, there is a $28.1 \%$ decrease of odds of food accessibility at household (Y2) for a one-unit increase in household poverty/economic status (X3). For a unit increase in number of school going children (X2), the odds in favor of food accessibility at household (Y2) decreases by (10.486 ) or about $51.4 \%$.

However, in the model, some of the variables show statistically significantly unexpected sign in respect to their relationship with household food security such as the climatic impacts on sanitation system (X60) and the incidences of disease (X44) show the odds in favor of availability of food at household (Y1). Similarly, climatic impact on household sanitation system (X60) and incidences of mosquitoes, insects, pest, etc. (X43) show the odds in favor of food accessibility at household (Y2). Therefore, new additional studies need to be undertaken to justify these unusual behavior of these few variables.

\subsection{Model Efficiency Test}

To identify if there are any multicollinearity problems present among the variables, the Pearson Correlation tests have been performed in the study. When two variables are considered highly correlated to each other in explaining the dependent variable, it may give rise to a multicollinearity problem. In case of multicollinearity, the correlation value is considered as 0.8 or above (Field, 2000: 2, 44-322). The result shows that the correlation values among the variables fall below 0.8 , which indicates that multicollinearity is absent among the variables.

Moreover, logically this study is free from endogeneity (including causality) problem because in the survey questions were asked about the impact of different factors on food security not vice versa. Moreover, technically the ordered dependent regression or ordinal regression is based on the "Generalized Linear Models" (used by EViews) and "Generalized structural equation model" (used by Stata) where the software itself takes some instrumental variables to solve the endogeneity problems.

\section{Conclusions and Policy Recommendations}

This study finds that several resilience factors, climatic factors, and non-climatic factors are statistically significant to explain the household status of food security. These variables also differ between food secure and insecure groups.

Climate change is one of the major potential threats for household food security in Malaysia (Alam et al., 2010, 2011). Therefore, to ensure sustainable household food security in the country, design of food security programs must integrate climatic change into the picture, and food security approaches must recognize climate change as an important driver. This integration also increases household capacity to adapt to climatic change. At the same time, climate change adaptation approaches and strategies to reduce vulnerability to climate change also increases household food security.

Prioritization of needs for investment targeted at increasing food security adaptation to climate change is important. Climate change adaptations are concentrated on improving 
the potential of people, especially the most vulnerable groups, toward adapting to climate changes. This involves support for livelihoods that are climate-resilient, reduction of disaster risk, advocacy, empowerment, and social mobilization to curb the underlying causes of vulnerability (Alam et al. 2012a). To adequately deal with the effects of climate change on food security, plans have to chalk out with a good analysis of the groups that are already particularly marginal at present. They are the most affected by climate change often, and they have very limited capacities to cope with.

Therefore, climate change affects groups that have always been at risk of food insecurity, and it also affects new groups who become vulnerable to regional weather changing conditions (IPCC, 2007). Most vulnerable groups already practice some form of risk management, but their capability to adapt to climatic changes is often limited due to their extremely restricted coping-up potential. Thus, the climate change adaptation techniques and food security should empower the groups that are socially excluded to lower their vulnerability and improve their resilience (Stern, 2007; Pielke et al., 2007; FAO, 1997). Work on adaptation must address food security as a main challenge faced by the populations that are vulnerable to the climate, while food security plans in most cases offer to people's capability to adapt to changes in climate, specifically when climate change is taken explicitly into consideration.

The mitigation options are important when planning for a long future. In the long run, the people who are vulnerable should be empowered and encouraged to adapt to climate change by developing resilience via investments in health, social protection, education, infrastructure, and other methods. Monitoring weather extremes and design strategies for disaster preparation are also very important. Given these effects and the resources needed to adapt them, resources that realize the Sustainable Development Goals (SDGs) might be integrated. Further, the private sector should advocate mitigation methods like energy efficiency, renewable energy, developments and infrastructure which include dams, floodresistant storage facilities, cyclone shelters, and techniques for lowering water loss in distribution systems, etc.

Finally, local, national, and regional administrations must be provided with adequate resources to deal with challenges of climate changes. They should put emphasis for the building of capacity in communities that are particularly at risk for food insecurity as well as climatic changes. We also suggest that new additional studies be undertaken to validate or reject the overall findings of our study. The findings of the study are empirically very new. Therefore, there are huge scopes to explore this issue further. The results of this study can be investigated further and validated against other socioeconomic factors, demographic factors, different locations, different economic groups, and different measurements of level of food security.

\section{Acknowledgement}

We are thankful to Ministry of Science, Technology and Environment of the Government of Malaysia for generously funding the research, under the Fundamental Research Grant Scheme of the Malaysian Ministry of Higher Education (FRGS/1/2012/SS07/UKM/01/3) and UKM Arus Perdana Research Grant Project (AP-2014-017).

\section{References}


Abdulai, A. \& CroleRees, A. 2001. Constraints to income diversification strategies: Evidence from Southern Mali. Food Policy 26 (4): 437-452.

Alam, M.M., Morshed, G., Siwar, C. \& Murad, M.W. 2012b. Initiatives and Challenges of Agricultural Crop Sector in ECER Development Projects in Malaysia, AmericanEurasian Journal of Agricultural \& Environmental Science 12 (7): 922-931.

Alam, M.M., Siwar, C., \& Al-Amin, A.Q. 2010. Climate Change Adaptation Policy Guidelines for Agricultural Sector in Malaysia, Asian Journal of Environmental and Disaster Management 2(4): 463-469.

Alam, M.M., Siwar, C., Molla, R.I., Talib, B., \& Mohd Ekhwan, T. 2012a. Paddy Farmers' Adaptation Practices to Climatic Vulnerabilities in Malaysia, Mitigation and Adaptation Strategies for Global Change 17(4): 415-423.

Alam, M.M., Siwar, C., Murad, M.W., \& Mohd Ekhwan, T. 2011. Farm Level Assessment of Climate Change, Agriculture and Food Security Issues in Malaysia. World Applied Sciences Journal 14(3): 431-442.

Alam, M.M., Siwar, C., Wahid, A.N.M., \& Talib, B. 2016a. Food Security and Low-Income Households in the Malaysian East Coast Economic Region: An Empirical Analysis. Review of Urban \& Regional Development Studies 28(1): 2-15.

Alam, M.M., Talib, B., Siwar, C. \& Mohd Ekhwan, T. 2014. Impacts of Climatic Changes on Paddy Production in Malaysia: Micro Study on IADA at North West Selangor, Research Journal of Environmental and Earth Sciences 6(5): 251-258.

Alam, M.M., Talib, B., Siwar, C., \& Wahid, A.N.M. 2016b. Climate Change and Food Security of the Malaysian East Coast Poor: A Path Modeling Approach. Journal of Economic Studies 43(3): 458-474.

Ali, R. \& Ali, A.K. 2009. Estimating the Prospective Impacts of Global Warming on Malaysian Agriculture. Proceeding of 2nd National Conference on Agro-Environment 2009, MARDI, Malaysia, Mar 24-26.

Arshad, F.M., Shamsudin, M.N. \& Saleh, R. 1999. Food Security in Malaysia, Presented at Seminar on International Trade and Food Security. Asian Productivity Organisation, Tokyo, Feb.

Baker, J.T. \& Allen, Jr. L.H. 1993. Contrasting crop species responses to $\mathrm{CO}_{2}$ and temperature: rice, soybean and citrus. Vegetatio 104/105: 239-260.

Bickel, G., Nord, M., Price, C., Hamilton, W. \& Cook, J. 2000. Guide to measuring household food security, revised 2000. Alexandria VA: US Department of Agriculture, Food and Nutrition Service.

Checkley, W., Epstein, L.D., Gilman, R.H., Figueroa, D., Cama, R.I., Patz, J.A. \& Black, R.E. 2000. Effects of El Niño and Ambient Temperature on Hospital Admissions for Diarrhoeal Diseases in Peruvian Children. The Lancet 355: 442-450.

Cline, W.R. 2007. Global Warming and Agriculture: Impact Estimates by Country. Washington, DC: Center for Global Development and Peterson Institute for international Economics.

Coates, J., Swindale, A. \& Bilinsky, P. 2007. Household Food Insecurity Access Scale (HFIAS) for Measurement of Household Food Access: Indicator Guide (v. 3). Washington, D.C.: Food and Nutrition Technical Assistance Project, Academy for Educational Development, Aug.

Cristofar S.P. \& Basiotis P.P. 1992. Dietary intakes and selected characteristics of women ages 19-50 years and their children ages 1-5 years by reported perception of food sufficiency. Journal of Nutrition Education 24:53-58.

Cruz, R.V., Harasawa, H., Lal, M., Wu, S., Anokhin, Y., Punsalmaa, B., Honda, Y., Jafari, M., Li, C. \& Huu Ninh, N. 2007. Asia. In: Parry, M.L., Canziani, O.F., Palutikof, J.P., van der Linden, P.J. \& Hanson, C.E. (eds.) Climate Change 2007: Impacts, 
Adaptation and Vulnerability. Contribution of Working Group II to the Fourth Assessment Report of the Intergovernmental Panel on Climate Change, Cambridge University Press, Cambridge, UK, pp. 469-506.

Curb Global Warming. 2007. Malaysia leads the world in greenhouse gas emission growth rate. (online) http://curbglobalwarmingblog.blogspot.com/2007/11/malaysia-leadsworld-in-greenhouse-gas.html (5 Jul 2012).

ECA. 2004. Land Tenure Systems and their Impacts on Food Security and Sustainable Development in Africa. Addis Ababa: ECA.

ECER Master Plan. 2007. Economic Drives of the Region- Agriculture, East Coast Economic Region Development Council.

ECER Master Plan. 2008. Key Targets, East Coast Economic Region (ECER) Master Plan, East Coast Economic Region Development Council. (online) http://www.ecerdc.com.my/en/master-plan/success-factors/ (accessed on 18 July 2016)

Energy Information Administration (EIA) 2005. International energy annual 2005 - CO2 world carbon dioxide emissions from the consumption of coal, 1980-2006 (Million Metric Tons of Carbon Dioxide). USA: Government of US.

FAO. 1997. Implications of Economic Policy for Food Security: A Training Manual. Training Materials for Agricultural Planning, 40. Rome: Food and Agriculture Organization of the United Nations.

FAO. 2003. Trade reforms and Food security: Conceptualizing the Linkages. Rome: Food and Agriculture Organization of the United Nations.

FAO. 2005. The State of Food Insecurity in the World 2005. Rome: Food and Agriculture Organization of the United Nations.

FAO. 2007. Food Outlook November 2007: High prices and volatility in agricultural commodities. Rome: Food and Agriculture Organization of the United Nations.

FAO. 2008. Climate Change and Food Security: A Framework Document, FAO interdepartmental working group on climate change, Rome: Food and Agriculture Organization of the United Nations.

Fartahun, M., Berhane, Y., Wall, S., Byass, P., Hogberg, U. 2007. Women's involvement in household decision making and strengthening social capital are crucial factors for child survival in Ethiopia. Acta Paediatrica 96:582-589.

Frankenberger, T. 1992. Indicators and Data Collection Methods for Assessing Household Food Security. In: Simon, M. \& Frankeberger, T.R. (eds.) Household Food Security: Concepts, Indicators, and Measurements: a technical Review, pp. 74-134. IFAD \& UNICEF, Rome \& New York.

Field, A. 2000. Discovering Statistics using SPSS for Windows, London: Sage Publications.

Hindin, M.J. 2006. Women's input in household decision and their nutritional status in three resource-constrained settings. Public Health Nutrition 9:485-493.

IPCC. 2007. Climate Change 2007- Impacts, adaptation and vulnerability. Contribution of Working Group II to the Fourth Assessment Report of IPCC. Cambridge. UK. Cambridge University Press.

Iram, U. \& Butt, M.S. 2004. Determinants of household food security: an empirical analysis for Pakistan. International Journal of Social Economics 31 (8):735-766.

Kovats, R.S., Edwards, S. Hajat, S. Armstrong, B., Ebi, K.L. \& Menne, B. 2004. The Effect of Temperature on Food Poisoning: Time Series Analysis in 10 European Countries. Epidemiology and Infection 132 (3): 443-453.

Kundzewicz, Z.W., Mata, L.J., Arnell, N.W., Döll, P., Kabat, P., Jiménez, B., Miller, K.A., Oki, T., Sen, Z., \& Shiklomanov, I.A. 2007. Freshwater resources and their management. In: Parry, M.L., Canziani, O.F., Palutikof, J.P., van der Linden, P.J. \& 
Hanson, C.E. (eds.) Climate Change 2007: Impacts, Adaptation and Vulnerability. Contribution of Working Group II to the Fourth Assessment Report of the Intergovernmental Panel on Climate Change, Cambridge University Press, Cambridge, UK, pp.173-210.

Lovendal, C.R. \& Knowles, M. 2006. Tomorrow's Hunger: A Framework for Analysing Vulnerability to Food Security, UNU- WIDER, Research Paper No. 2006/119.

Mimura, N., Nurse, L., McLean, R.F., Agard, J., Briguglio, L., Lefale, P., Payet, R. \& Sem, G. 2007. Small Islands. In: Parry, M.L., Canziani, O.F., Palutikof, J.P., van der Linden, P.J. \& Hanson, C.E. (eds.) Climate Change 2007: Impacts, Adaptation and Vulnerability. Contribution of Working Group II to the Fourth Assessment Report of the Intergovernmental Panel on Climate Change, Cambridge University Press, Cambridge, UK, pp. 687-716.

MOSTE, 2001. National Response Strategies to Climate Change. Ministry of Science, Technology and the Environment, Putrajaya, Malaysia.

Myntti, C. 1993. Social determinants of child health in Yemen. Social Science \& Medicine $37: 233-240$.

NAHRIM. 2006. Final Report: Study of the Impact of Climate Change on the hydrologic Regime and Water Resources of Peninsular Malaysia, National Hydraulic Research Institute of Malaysia (NAHRIM) and California Hydrologic Research Laboratory (CHRL), Malaysia.

Nyariki, D.M. \& Wiggins, S. 1997. Household Food insecurity in Sub-Saharan Africa: Lesson from Kenya. British food journal 99 (7): 249-262.

Pfeiffer, J., Gloyd, S., Ramirez, L.L. 2001. Intra-household resource allocation and child growth in Mozambique: an ethnographic case-control study. Social Science \& Medicine 53:83-97.

Piaseu, N. 2006. Factors affecting food insecurity among urban poor in Thailand. South African Journal of Clinical Nutrition 18:156-160.

Pielke, R., Prins, G., Rayner, S. \& Sarewitz, D. 2007. Lifting the taboo on adaptation. Nature 445(7128): 597-598.

Singh, S., Amartalingam, R., Wan Harun, W.S. \& Islam, M.T. 1996. Simulated impact of climate change on rice production in Peninsular Malaysia. Proceeding of National Conference on Climate Change. pp. 41-49, UPM, Malaysia.

Stern, N. 2007. The Economics of Climate Change: The Stern Review. Cambridge University Press: Cambridge.

Tashiro, T. \& Wardlaw, I.F. 1989. A comparison of the effect of high temperature on grain development in wheat and rice. Annals of Botany 64: 59-65.

Thomsen, A. \& Metz, M. 1998. Implications of economic policy for food security: A training manual. Rome. FAO and the German Agency for Technical Cooperation (GTZ).

Tisdell, C. 1996. Economic indicators to assess the sustainability of conservation farming projects: An evaluation. Agriculture, Ecosystems and Environment 57 (2): 117-131.

Von Braun, J. 2007. The World Food Situation: New Driving Forces and Required Actions. Food Policy Report. Washington, DC: IFPRI.

Workneh, N. 2006. Determinants of small farm household food security: evidence from south Wollo, Ethiopia. Ethiopian Journal of Development Research 28 (1): 1-29.

Yamane, T. 1967. Statistics: An introductory analysis. Edition 2. New York: Harper and Row.

Zimmerman, M., DePaola, A., Bowers, J.C., Krantz, J.A., Nordstrom, J.L., Johnson, C.N. \& Grimes, D.J. 2007. Variability of Total and Pathogenic Vibrio Parahaemolyticus Densities in Northern Gulf of Mexico Water and Oysters. Applied and Environmental Microbiology 73 (23): 7589-7596. 


\section{Appendix: List of the variables}

Y1 Household food availability in the last one month, where available enough of the kinds of food you want to eat $=1$, others $=0$.

Y2 Household status of food accessibility, where food secure access $=1$, others $=0$

$\mathrm{X} 1 \quad$ Education level, where illiterate $=1$, primary $=2$, secondary $=3$, certificate $=4$

$\mathrm{X} 2$ Number of school going children, where no school going children $=1,1-2$ children $=2,3$ children $=3,4-5$ children $=4$, more than 5 children $=5$

X3 Household poverty/economic status, where marginally non-poor=1,recently marginally non-poor $=2$, poor $=3$, hard core poor $=4$

X4 Spouse doing job, where yes $=1$, no $=0$

X5 Head of household having supplementary job, where yes $=1$, no $=0$

X6 Earning Ratio (Earning Family Member / Total Family Member) is coded in 1-5 scale based on equal value for every $20 \%$ ratio value, where $0-20 \%, 21-40 \%, 41-60 \%, 6-$ $80 \%$, and $81-100 \%$ are coded as $1,2,3,4,5$ respectively.

X7 Household having any savings, where yes $=1$, no $=0$

X8 Locality, where urban $=1$,rural $=0$

X9 Ownership of house, where yes $=1$, no $=0$

X10 Type of home, where wood made $=1$, mixed $=2$, brick $=3$

X11 Household having any transport for buying food, where yes $=1, \mathrm{no}=0$

X12 Household buying bulk amount of food, where yes $=1$, no $=0$

X13 Household having neat and clean kitchen and dining place, where yes $=1, \mathrm{no}=0$

X14 Household having a hygienic sanitation facility, where strongly disagree $=1$, disagree $=2$, not sure $=3$, agree $=4$, strongly agree $=5$

X15 Household managing waste properly, where strongly disagree $=1$, disagree $=2$, not sure $=3$, agree $=4$, strongly agree $=5$

X16 Household having knowledge about maintaining nutritious and hygienic way of cooking and washing food, where strongly disagree $=1$, disagree $=2$, not sure $=3$, agree $=4$, strongly agree $=5$

X17 Household having knowledge about taking precaution against dengue, malaria, etc., where strongly disagree $=1$, disagree $=2$, not sure $=3$, agree $=4$, strongly agree $=5$

X18 The effectiveness of current food distribution process in Malaysia, where very low $=1$, low $=2$, normal $=3$, high $=4$, very high $=5$

X19 Current road and transportation facility for food distribution process in Malaysia, where very low $=1$,low $=2$, normal $=3$, high $=4$, very high $=5$

X20 Availability of expected food in the local market, where very low $=1$, low $=2$, normal $=3$, high $=4$, very high $=5$

X21 Sufficiency of expected food in the local market, where very low $=1$, low $=2$, normal $=3$, high $=4$, very high $=5$

X22 Current prices of general food items, where very low $=1$, low $=2$, normal $=3$, high $=4$, very high $=5$

X23 Current difference between rural and city food prices, where very low $=1$, low $=2$, normal $=3$, high $=4$, very high $=5$

X24 High prices of food cause household food shortage, where very low $=1$, low $=2$, normal $=3$, high $=4$, very high $=5$

X25 Current level of household income, where very low=1,low=2,normal=3, high=4, very high $=5$ 
X26 Low level of income cause household food shortage, where very low $=1$, low $=2$, normal $=3$, high $=4$, very high $=5$

X27 Ready budget arrangement to buy food anytime, where very low $=1$, low $=2$, normal $=3$, high $=4$, very high $=5$

X28 Availability of discount or offer on food price in the local market, where very low $=1$, low $=2$, normal $=3$, high $=4$, very high $=5$

X29 The effectiveness of current food distribution process in Malaysia, where very low $=1$, low $=2$, normal $=3$, high $=4$, very high $=5$

X30 Dependency on common resources for cattle or livestock feeding, where very low $=1$, low $=2$, normal $=3$, high $=4$, very high $=5$

X31 Current competition among people for common resources, where very low $=1$, low $=2$, normal $=3$, high $=4$, very high $=5$

X32 Current expenditure for feeding and medicine of cattle and livestock, where very low $=1$, low $=2$, normal $=3$, high $=4$, very high $=5$

X33 Difference between rural and city food quality, where very low $=1$, low $=2$, normal $=3$, high $=4$, very high $=5$

X34 Food quality or nutrition level in local market, where very low $=1$, low $=2$, normal $=3$, high $=4$, very high $=5$

X35 Food quality on food safety in local market, where very low $=1$,low $=2$, normal $=3$, high $=4$, very high $=5$

X36 Quality of drinking water, where very low=1,low=2, normal=3, high=4, very high=5

X37 Stability of food price, where very low $=1$,low $=2$, normal $=3$, high $=4$, very high $=5$

X38 Price variation among shops in the local market, where very low $=1$, low $=2$, normal $=3$, high $=4$, very high $=5$

X39 Access of quick credit to buy food, where very low $=1$, low $=2$, normal=3, high $=4$, very high $=5$

X40 Stability of food supply, where very low=1,low=2, normal=3, high=4, very high=5

X41 Unavailability of food in market leading food shortage, where very low $=1$, low $=2$, normal $=3$, high $=4$, very high $=5$

X42 Agencies supports for household food security, where very low $=1$, low $=2$, normal $=3$, high $=4$, very high $=5$

X43 Current level of incidences of mosquitos, insects, pest, etc., where very low $=1$,low $=2$, normal $=3$, high $=4$, very high $=5$

X44 Current level of incidences of disease like dengue, malaria, heat stretch, cold, skin disease, etc., where very low $=1, \mathrm{low}=2$, normal $=3$, high $=4$, very high $=5$

X45 Occurrences of natural disasters such as flood, cyclone, landslides, etc. at local level, where very low $=1$,low $=2$, normal $=3$, high $=4$, very high $=5$

$\mathrm{X} 46$ Climatic issues and related disease reduces income, where yes $=1, \mathrm{no}=0$

X47 Climatic issues affect household food collection system, where strongly disagree $=1$, disagree $=2$, not sure $=3$, agree $=4$, strongly agree $=5$

X48 Climatic issues affect household food storage system (e.g. Refrigerator, packaging, etc.), where strongly disagree $=1$, disagree $=2$, not sure $=3$, agree $=4$, strongly agree $=5$

X49 Climatic issues affect household food storage process (e.g. Dry, salty, oily, etc.), where strongly disagree $=1$, disagree $=2$, not sure $=3$, agree $=4$, strongly agree $=5$

X50 Climatic issues increase household food storage cost, where strongly disagree $=1$, disagree $=2$, not sure $=3$, agree $=4$, strongly agree $=5$

X51 Climatic issues affect household usage or utilization of land, where strongly disagree $=1$, disagree $=2$, not sure $=3$, agree $=4$, strongly agree $=5$

X52 Climatic issues reduce normal food test, where strongly disagree $=1$, disagree $=2$, not sure $=3$, agree $=4$, strongly agree $=5$ 
X53 Climatic issues reduce food longevity, where strongly disagree $=1$, disagree $=2$, not sure $=3$, agree $=4$, strongly agree $=5$

X54 Climatic issues affect household food choice and habit, where strongly disagree $=1$, disagree $=2$, not sure $=3$, agree $=4$, strongly agree $=5$

X55 Climatic issues affect household cooking system (e.g. Cooking by gas or stove not by woods), where strongly disagree $=1$, disagree $=2$, not sure $=3$, agree $=4$, strongly agree $=5$

X56 Climatic issues affect cooking time and amount (e.g. large amount of cooking together or several time cooking for hot food or several times heating for not rotating), where strongly disagree $=1$, disagree $=2$, not sure $=3$, agree $=4$, strongly agree $=5$

X57 Climatic issues cause to eat outside or buy ready food from outside, where strongly disagree $=1$, disagree $=2$, not sure $=3$, agree $=4$, strongly agree $=5$

X58 Climatic issues affect the environment and cleanness of kitchen, where strongly disagree $=1$, disagree $=2$, not sure $=3$, agree $=4$, strongly agree $=5$

X59 Climatic issues affect household waste management, where strongly disagree $=1$, disagree $=2$, not sure $=3$, agree $=4$, strongly agree $=5$

X60 Climatic issues affect home sanitation system, where strongly disagree $=1$, disagree $=2$, not sure $=3$, agree $=4$, strongly agree $=5$

X61 Climatic issues hamper food aid services and food supports program, where strongly disagree $=1$, disagree $=2$, not sure $=3$, agree $=4$, strongly agree $=5$

X62 Climatic issues increase short term food prices, where strongly disagree $=1$, disagree $=2$, not sure $=3$, agree $=4$, strongly agree $=5$

X63 Climatic issues cause to increase food price in restaurant, where strongly disagree $=1$, disagree $=2$, not sure $=3$, agree $=4$, strongly agree $=5$ 